\title{
Unwelcome arrivals
}

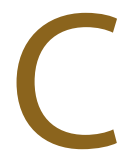

alifornia's numerous ports of entry and borders provide plenty of opportunities for exotic and invasive insects, weeds and plant diseases to enter the state. Some of these species are intentionally introduced, while others arrive accidentally. Once here, they can benefit from the lack of natural controls of their native environments and thrive in new plant or animal systems and management practices. Here are five significant and new arrivals to California under investigation by UC scientists.

\section{Polyphagous shot hole borer}

In 2012, a South Gate (Los Angeles County) homeowner was searching the Internet to identify mysterious symptoms in her backyard avocado tree. She found Akif Eskalen, UC Cooperative Extension (UCCE) specialist in the Department of Plant Pathology at UC Riverside, and emailed pictures.

"As soon as I got the pictures, I realized it was something I had never seen before," Eskalen said.

He visited the South Gate residence and identified the polyphagous shot hole borer, a tiny beetle from Asia that bores through bark carrying with it a harmful fungus (Fusarium euwallacea). The fungus attacks the

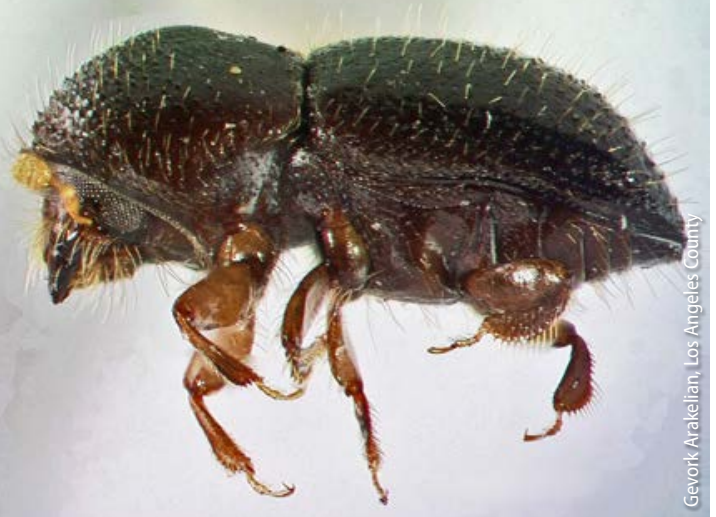

UC Riverside scientists are researching control measures for the polyphagous shot hole borer, an invasive beetle from Asia that bores into trees and transmits a pathogenic fungus. tree's vascular tissue, choking off water, causing branch dieback and eventually killing the tree. Polyphagous shot hole borer and the fungus are now distributed widely in more than 110 types of trees in Los Angeles and Orange counties, and have been observed in San Bernardino, Riverside and San Diego counties. So far, infested trees are mostly urban, but agriculturally important trees like olive and persimmon, as well as avocado, are known hosts.

Eskalen is conducting research aimed at defeating the fungus, UC Riverside entomologist Richard Stouthamer is researching the beetle's origin and UC Riverside entomologist Timothy Paine is studying control measures for the beetle. Until solutions to the problem can be found, the

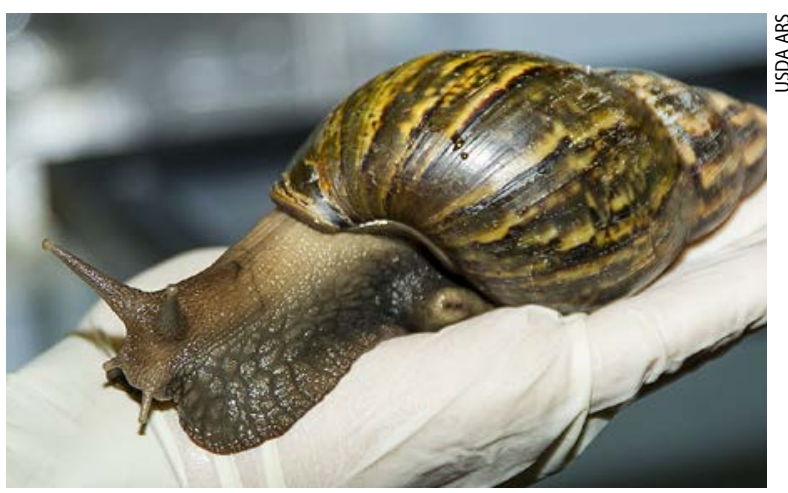

In July 2014, the USDA intercepted a shipment of giant African snails (shown

scientists are asking the public to help prevent the spread of this pest.

"If you have heavily infested plant material, remove it, chip it and cover it with a plastic tarp to get rid of the colony," Eskalen said. "Never move infested material to non-infested areas."

\section{Giant African snail} above in an official's hand) in Los Angeles. Although the snails haven't reached the wild in California, UC researchers are working with scientists in Florida, where officials are trying to eradicate an infestation discovered in 2010.

When 68 giant African snails were intercepted at Los Angeles International Airport in July 2014, the news went viral. Gardeners, farmers and researchers were unnerved by a broadly circulated photo showing snails the size of grapefruits that had been seized in a shipment from Nigeria.

Giant snails have a wide host range and feed voraciously. Besides causing crop damage, the snails can transmit a parasitic nematode that can lead to meningitis in humans.

The giant snails haven't made it into the wild in California, but UC Riverside entomologist Jocelyn Millar is working closely with scientists in Florida, where officials are trying to eradicate an infestation discovered in 2010. Giant snails are difficult to root out because the small, newly hatched snails are hard to find, and when fully grown they are adept at hiding in foliage and leaf litter. Millar, an expert on pheromone attractants, is looking for natural attractants that will draw them out of hiding and into traps. He is working on the project with UC Riverside research specialist Rory McDonnell, who is an expert on snail and slug biology, and Amy Roda, a U.S. Department of Agriculture Animal Plant Health Inspection Service (USDA APHIS) scientist specializing in invasive species. 


\section{Quagga mussel}

In 2010, officials were alarmed to learn that quagga mussel had invaded Lake Piru, a reservoir on the Ventura County-Los Angeles County border. A native of Ukraine, the freshwater pest made its way to the U.S. Great Lakes in 1989. In 2007 they were found in Lake Mead and other lakes on the Colorado River. At this time, it is not known how quagga reached Lake Piru. It is the first appearance of the invasive pest in a California water body that is not fed by the Colorado River.

Quagga mussels multiply rapidly, encrusting boat hulls, engines and equipment, and clogging water pipes up to two feet in diameter. They are voracious filter feeders, clearing plankton from lakes that is needed by native species.

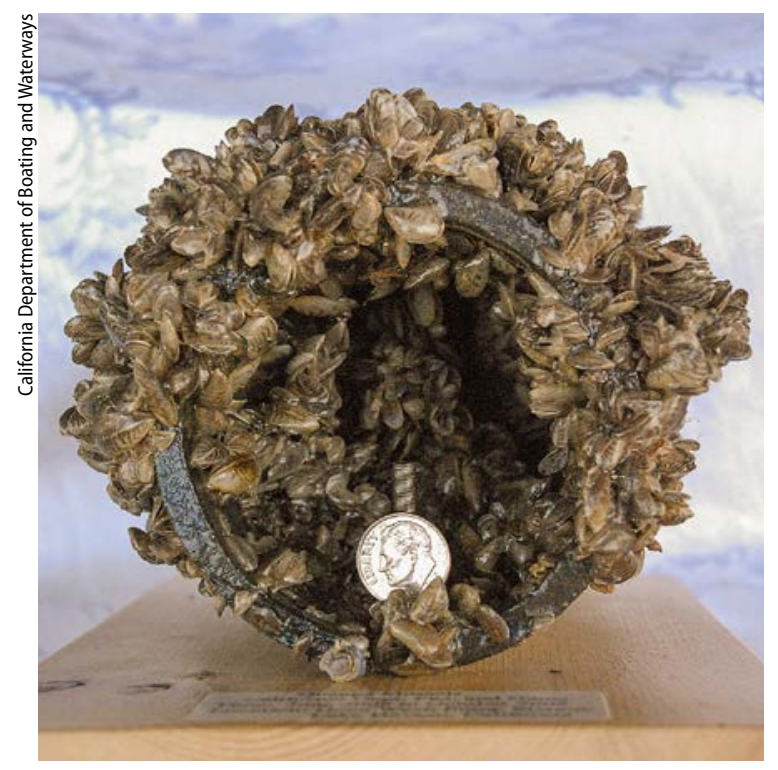

Quagga mussels, native to Ukraine, encrust boat hulls, engines and equipment, and clog water pipes.

Greg Giusti, UCCE advisor in Lake County, is working closely with county officials to

keep quagga mussels out of Clear Lake, the largest natural freshwater lake in California. Guisti helped the county draft an ordinance requiring regular inspections of boats launched in Clear Lake. The local media, the Internet, the

California Department of Fish and Wildlife and the vast fishing community were part of an outreach effort to make people aware of the regulation. Failing to comply results in a fine up to $\$ 1,000$.
"One thing in our favor is that surrounding lakes are also uninfested," Giusti said. "If quagga make it to Shasta, Folsom or Berryessa lakes, we're toast."

The most common way mussels are moved is recreational boating, but that's not the only threat.

For example, it is common practice for fire-

\section{"If quagga make it to Shasta, Folsom or Berryessa lakes, we're toast."}

- Greg Giusti

fighting agencies to dip

equipment into lakes to collect water to fight fire.

Sabrina Drill, UCCE advisor for Los Angeles and Ventura counties, briefed firefighting officials about ways to prevent spreading the invasive species.

"It might be OK to use water from Lake Piru to fight a fire in Lake Piru's own watershed," Drill said. "I shared best management practices for decontaminating the equipment that was in contact with the infested water - starting with making sure everything is drained and completely dried before it is used in another lake."

\section{Brown marmorated stink bug}

“They're here," wrote UCCE advisor Chuck Ingels in a September 2013 email to Sacramento growers. He had just visited the midtown Sacramento site where hundreds of brown marmorated stink bugs (BMSB; Halyomorpha halys) were clustered together on a Chinese pistache street tree.

Comments, emails and calls began pouring in. "These bugs were horrible when I lived in Pennsylvania," commented Todd Jumper on the UC Agriculture and Natural Resources (ANR) website. "Hundreds of them in our home and (it was) literally almost impossible to stop them."

BMSB is a pest of agricultural crops and a serious residential problem. It is a strong flyer and also travels long distances by hitching rides in vehicles or inside furniture or other articles when they are moved, often in late summer and early fall. As a result, new infestations pop up in neighborhoods where people travel from infested areas.

A native of China, Japan and Korea, BMSB was first documented in the United States in Pennsylvania in 2001. It is either established or found occasionally in about 41 states.

BMSB feeds on apples, pears, cherries, peaches, corn, beans, tomatoes, berries and many other California crops. Feeding creates pock marks and distortions that make the fruit
Brown marmorated stink bug, a pest of fruit and vegetable crops, was first discovered in the United States in Pennsylvania. In California, reproducing populations have been found in Los Angeles County and Sacramento. 


\section{Research news \\ "In certain respects, [the brown marmorated stink bug] is one of the worst invasive pests we've ever had in California." —Chuck Ingels \\ unmarketable. In grapes, berries collapse and rot increases. Wine tasters have been able to detect stink bug odor in wines made from grapes that} had as little as one bug per three clusters.

"In certain respects, this is one of the worst invasive pests we've ever had in California," Ingels said.

In summer 2014, Ingels conducted a monitoring program for BMSB in Sacramento County funded by the California Pear Advisory Board and the Lodi Winegrape Commission. Ingels said his team documented the population fluctuations of BMSB in midtown Sacramento. He found no bugs in traps near farms south of Sacramento along the Sacramento River. UCCE advisors Lucia Varela and Rachel Elkins, also with funding from the Pear Advisory Board, conducted BMSB monitoring programs in Lake and Mendocino counties; none were found.

"They don't seem to be spreading fast," Ingels said. "We've learned that it takes four or five years for a major reproducing population to build up. That suggests they could be on farms, but we haven't found them yet."

In the meantime, problems persist in midtown Sacramento.

"Restaurants are concerned that the stink bugs are visible on the walls and crawling on tables. A couple of apartment managers called me to say their tenants are threatening to move out if they are not controlled," Ingels said. "They are a nuisance, so they are already having an economic impact."

\section{Downy mildew}

In the plant disease world, the introduction of new pests is more ambiguous than with insects. In Imperial County, for example, farmers are dealing with a new race of downy mildew in spinach (Peronospora farinosa f. sp. spinaciae).

"We don't know where it may have come from," said Steven Koike, UCCE plant pathologist for Monterey and Santa Cruz counties. "It could have come in from other countries, or it might have mutated here in California. There's some suspicion viable downy mildew is carried on seed, but the evidence at this point is all circumstantial."

They do know an Imperial Valley grower noticed bright yellow blotches staining spinach leaves in 2012. It wasn't long before samples were delivered to Koike, who operates UCCE's only county-based plant diagnostic lab.

"We have developed a very strong relationship with industry over the years," Koike said. "When growers start to see some breakdown in previously resistant varieties, they get in touch with me."

Downy mildew will not grow in petri dishes, only on living tissue. Koike and his team washed the spores off the sample leaves and sprayed them onto 12 varieties of spinach in the lab. They assign a plus or minus to each variety based on which come down with the disease and which stay healthy.

"This creates a fingerprint of the pathogen," Koike said. "We match the fingerprint to see if it is a known race. In this case, it was a brand new fingerprint, so we realized we likely had a new race."

\section{"When growers start to see some breakdown in previously resistant varieties, they get in touch with me." - Steven Koike}

The same test was conducted by James Correll, a plant pathologist at the University of Arkansas and Koike's frequent collaborator, who reached the same conclusion. In 2014, the International Working Group on Peronospora farinosa (IWGP) in The Netherlands designated Koike and Correll's isolate as race Pfs: 15.

The IWGP promotes consistent and clear communication between public and private entities - scientists, farmers, plant breeders and others - about all resistance-breaking races that affect a wide area and cause significant economic impact. Koike and Correll's work contributed to this international effort. CA -Jeannette Warnert
The new race of downy mildew stains spinach leaves with bright yellow blotches. 